\title{
TAXONOMY OF PHOTO CATEGORIES
}

\author{
IWAN ZAHAR* \\ KURNIA SETIAWAN** \\ TENGKU FAUZAN TENGKU ANUAR ${ }^{\star * *}$
}

iwan.zahar@esaunggul.ac.id ${ }^{*}$, kuniast@fsrd.untar.ac.id**, tengkufauzan@umk.edu.my***

\begin{abstract}
Selecting photographs for teaching photo criticism can be a difficult task. This research aims to construct the taxonomy of photo categories for teaching purposes and teaching guidelines. This research used a questionnaire and a semi-structured interview with 125 participants made up of 39 male and 86 female, 94 Malays, 12 Chinese, 16 Indians and 3 Ibans. All participants exposed to five different photographs: advertising photographs, journalistic photographs, landscapes, and two fine arts photographs. We used three questions as research instruments for 125 participants to judge each photo: What do you see? What does it mean? How do you know? Also, we used Barrett's criticism models to teach, make a rubric, and evaluate the photographs and our research instruments. From our photo teaching experience, combined with this research, students usually started from low taxonomies. They followed through to high taxonomies, or in a sequence from advertising photographs, journalistic photographs, and landscapes (fine art) to modernist photographs and postmodernist photographs (fine art). They did not have difficulty interpreting elements, design principles, and photo techniques, but they did construct it challenging to analyze the context of postmodern photographs, especially gender issues.
\end{abstract}

Keywords: Barrett's Criticism Model, Categories, Modernist Photo, Photography, Postmodernist Photo Taxonomies

** Lecturer at Design Visual Communication, Faculty of Arts and Design, Tarumanagara University, Indonesia

*** Senior Lecturer at Faculty of Creative Technology and Heritage / Institute of Research and Management for Poverty, Universiti Malaysia Kelantan, Malaysia 


\title{
TAKSONOMI KATEGORI FOTO
}

\author{
IWAN ZAHAR* \\ KURNIA SETIAWAN** \\ TENGKU FAUZAN TENGKU ANUAR ${ }^{* * *}$ \\ iwan.zahar@esaunggul.ac.id*, kuniast@fsrd.untar.ac.id**, tengkufauzan@umk.edu.my***
}

\begin{abstract}
Abstrak
Memilih gambar untuk mengajar kritikan foto boleh menjadi tugas yang sukar. Penyelidikan ini bertujuan untuk membina taksonomi kategori foto untuk tujuan pengajaran dan panduan pengajaran. Penyelidikan ini menggunakan soal selidik dan temu bual separa berstruktur dengan 125 peserta terdiri daripada 39 lelaki dan 86 perempuan, 94 orang Melayu, 12 orang Cina, 16 orang India dan 3 orang Iban. Semua peserta terdedah kepada lima gambar yang berbeza: foto iklan, foto jurnalistik, pemandangan, dan dua gambar seni rupa. Kami menggunakan tiga soalan sebagai instrumen kajian untuk 125 peserta menilai setiap foto: Apa yang anda lihat? Apakah maksudnya? Bagaimana anda tahu? Kami juga menggunakan model kritikan Barrett untuk mengajar, membuat rubrik, dan menilai gambar dan instrumen kajian kami. Dari pengalaman mengajar foto kami, digabungkan dengan penyelidikan ini, pelajar biasanya bermula dari taksonomi standard. Mereka mengikuti hingga taksonomi tinggi, atau dalam urutan dari foto iklan, foto jurnalistik, dan pemandangan (seni rupa) hingga foto modernis dan foto pascamoden (seni rupa). Mereka tidak mengalami kesukaran untuk menafsirkan elemen, prinsip reka bentuk, dan teknik foto, tetapi mereka membuatnya sukar untuk menganalisis konteks foto pascamoden, terutama masalah gender.
\end{abstract}

Kata Kunci: Model Kritikan Barrett, Foto Modernis, Fotografi Kategori, Taksonomi Foto Pascamoden Indonesia

** Pensyarah di Desain Komunikasi Visual, Fakultas Seni Rupa dan Desain, Tarumanagara University, Indonesia

*** Pensyarah Kanan di Fakulti Teknologi Kreatif dan Warisan / Institut Penyelidikan dan Pengurusan Kemiskinan (InsPeK), Universiti Malaysia Kelantan, Malaysia 
Since Roland Barthes' camera lucida in 1981 and Susan Sontag's on photography in 1977, photo criticism or photo theory has only recently evolved. However, most students at Tarumanagara University in Jakarta (Zahar, 2010),Universiti Malaysia Kelantan (UMK) students from 2011 to 2017, and my most recent webinar (Zahar, 2021) demonstrated that they were unable to understand and critics photographs when I first showed them the photographs (pretest), include some of professional photographers or wedding photographers during my webinar. Many researchers in Indonesia or student published journals which relates to photo criticism because they think it is important to improve their visual literacy ((Frawisandi, 2015; Gaya, 2019; (Rafika Dhona dan Astari, 2020); Wulandari, 2017)

Many photo experts have made types of photographs or photo categories from Barrett, 1986; 2006; Minor White, 1950; Newhall, 1964; Ward, 1970. The medium of photography accommodates a massive diversity of pictures, some of which photographs are made to express the purpose of being art and somewhere they are not (Barrett, 1986). Alternatively, photographs can be used for one purpose and then used differently later. One such case was when Oliviero Toscani used a 1991 World Press Photo as part of a United Colours of Benetton ad. The captions and the use of the photograph were what determined how people read the image.

Similarly, at the Café (1958), Robert Doisneau's photograph was first published in Le Point as part of a photo essay on Paris cafés. Still, it was later sold without Doisneaus's consent to a temperance league and published in a leaflet about alcohol abuse. Again, it was used by a French gossip tabloid and printed with the caption' Prostitution on the ChampsElysees". However, the caption changed again when this photo was exhibited and became part of The Museum of Modern Art (Barrett, 2010). Thus, photography derives meaning from its context (Becker, 1998). These four contextual situations explain how a photograph can function as a press photograph, but how it is the captions that guide the observer to interpret different meanings. The first three contextual photographs served as press photograph, but the fourth contextual photograph becomes fine art. This caused by the photograph displayed in the Museum of Modern Art, New York ((Barrett, 1997). Although Robert Doisneau's photo has four different external contexts, students had no difficulty interpreting the press photo.

Modernism emphasizes photo techniques such as no manipulation of the exposed negative, prints are not manipulated, contain a rich range of grey tones, etc. (Kohler, 1989, Zahar 2015. According to Salomon-Godeau and Grover (Barrett, 2006), postmodernism in photography embraced that art exemplifies the cultural, political, and psychological experience. The postmodernism style favours content over form and represents a plurality of techniques. Postmodernism is willing to borrow widely from the past and returned to the figurative in art. Our teaching experience is the postmodernist photographers, especially Cindy Sherman and Lorna Simpson, who have difficulty interpreting photography. Parson (2002) indicated that the meaning of an artwork constructed by the viewer's interactions and the works, including the viewer's culture. Cindy Sherman and Lorna Simpson promote feminist issues that are not the students' culture in these institutions. 
We proposed categories which are a hierarchy in the interpretation of photographs to sort out photographs. The categories can be used for preparing the lesson materials. In our experience, some photographs will be difficult to interpret without previous knowledge about the history of photography, the artist's biography, and social issues of the photographs. Students must employ art criticism models to interpret the photographs.

\subsection{Art Criticism Model}

Art Criticism models have been developed by many philosophers and art experts (Barrett, 2006; Broudy, 1986; Clements, 1979; Feldman, 1994; Hamblen, 1984; Johansen, 1979; Lankford, 1984; Mitler, 1980). One of the most popular is the Feldman Criticism Model, which is simple and contains only four steps: description, formal analysis, interpretation, and judgement. Barrett's Criticism model is similar to Feldman's, but the contextual information is divided into three parts: internal, original and external context. We favour Barrett's criticism model for photo interpretation because Chia used the model (2005) and Zahar (2010) and some lecturer photography in Malaysia (Mustaffa Halabi Hj. Azahari, April 30, 2015, personal communication). The photographs' internal context describes the subject matter, form, medium, denotation, and connotation.

In contrast, the original context refers to the conditions under which the photograph was made and the photograph style. To be more specific, it considers the photographer's original context, biography, intellect, stylistic sources of the work, the relation of the photograph to others contemporary, and the social, political, philosophical, and religious characters of the times. External context refers to the situation in which a photograph is presented or found. Every photograph is intentionally or accidentally situated within a context. We can see photographs on the internet, in books, galleries, newspapers, museums, magazines, billboards, and classrooms.

Any photograph's meaning is highly dependent on the context in which it appears as illustrated in Table 1 (Barrett, 2006). This is where evaluation is different from interpretation. Interpretations are statements about the meaning of an artwork, whereas judgments are statements about an image's worth. When critics happen to judge photographs, they usually praise them, but sometimes they can find fault with them as indicated in Table 2 (Barrett, 2006). In other words, judging is the action where the learner decides what type of art is being examined by comparing it to the Theories of Art. Once the kind of art is determined, the learner chooses how effectively the artwork conforms to the established criteria for artwork placed in that aesthetic theory and then literally judges its success or quality accordingly (Prater, 2002).

Table 1: Barrett's criticism model

(Source: Barrett, 2006)

\begin{tabular}{|l|l|l|}
\hline $\begin{array}{l}\text { Internal } \\
\text { Context }\end{array}$ & Subject & \multicolumn{1}{|c|}{ Description } \\
\cline { 2 - 3 } & Subject matter & $\begin{array}{l}\text { Descriptive statements about subject matter identify } \\
\text { and typify person, objects, places, or events in a } \\
\text { photograph. When describing the subject matter, } \\
\text { critic's name what they see and also characterize it. }\end{array}$ \\
\cline { 2 - 3 } & Form & $\begin{array}{l}\text { How the subject matter is presented. Descriptive } \\
\text { statements about a photograph form concern how it is }\end{array}$ \\
\hline
\end{tabular}




\begin{tabular}{|l|l|l|}
\hline \multirow{1}{*}{} & & $\begin{array}{l}\text { composed, arranged and constructed visually. } \\
\text { Describe also formal elements and principles of } \\
\text { designs. }\end{array}$ \\
\cline { 2 - 3 } & Medium & $\begin{array}{l}\text { An art object is made of. Describe the process, the } \\
\text { type of camera, the kind of prints, and discuss its } \\
\text { effects on the expression and overall impact. }\end{array}$ \\
\cline { 2 - 3 } & Denotation & $\begin{array}{l}\text { Show. Denotation often refers to something literal and } \\
\text { avoids being a metaphor. }\end{array}$ \\
\cline { 2 - 3 } Context & Connotation & $\begin{array}{l}\text { Suggest, imply. Which is the second level of analysis, } \\
\text { being what the denotation represents? }\end{array}$ \\
\hline & Style & $\begin{array}{l}\text { A resemblance among diverse art objects from an } \\
\text { artist, movement, period, or geographic location is } \\
\text { recognized by characteristic handling of subject matter } \\
\text { and formal elements. }\end{array}$ \\
\cline { 2 - 3 } & $\begin{array}{l}\text { Comparing } \\
\text { and } \\
\text { contrasting }\end{array}$ & $\begin{array}{l}\text { To compare and contrast it to other works by the same } \\
\text { photographer, other photographers work or works by } \\
\text { other artists. }\end{array}$ \\
\hline $\begin{array}{l}\text { External } \\
\text { context }\end{array}$ & $\begin{array}{l}\text { Photograph's } \\
\text { presentation } \\
\text { environments }\end{array}$ & $\begin{array}{l}\text { How and where it is being presented, has been } \\
\text { submitted, received, how other interpreters have } \\
\text { understood it, where it has been placed in the history } \\
\text { of art. }\end{array}$ \\
\hline
\end{tabular}

Table 2: Example of Barrett's criticism model

(Source: Barrett, 2006)

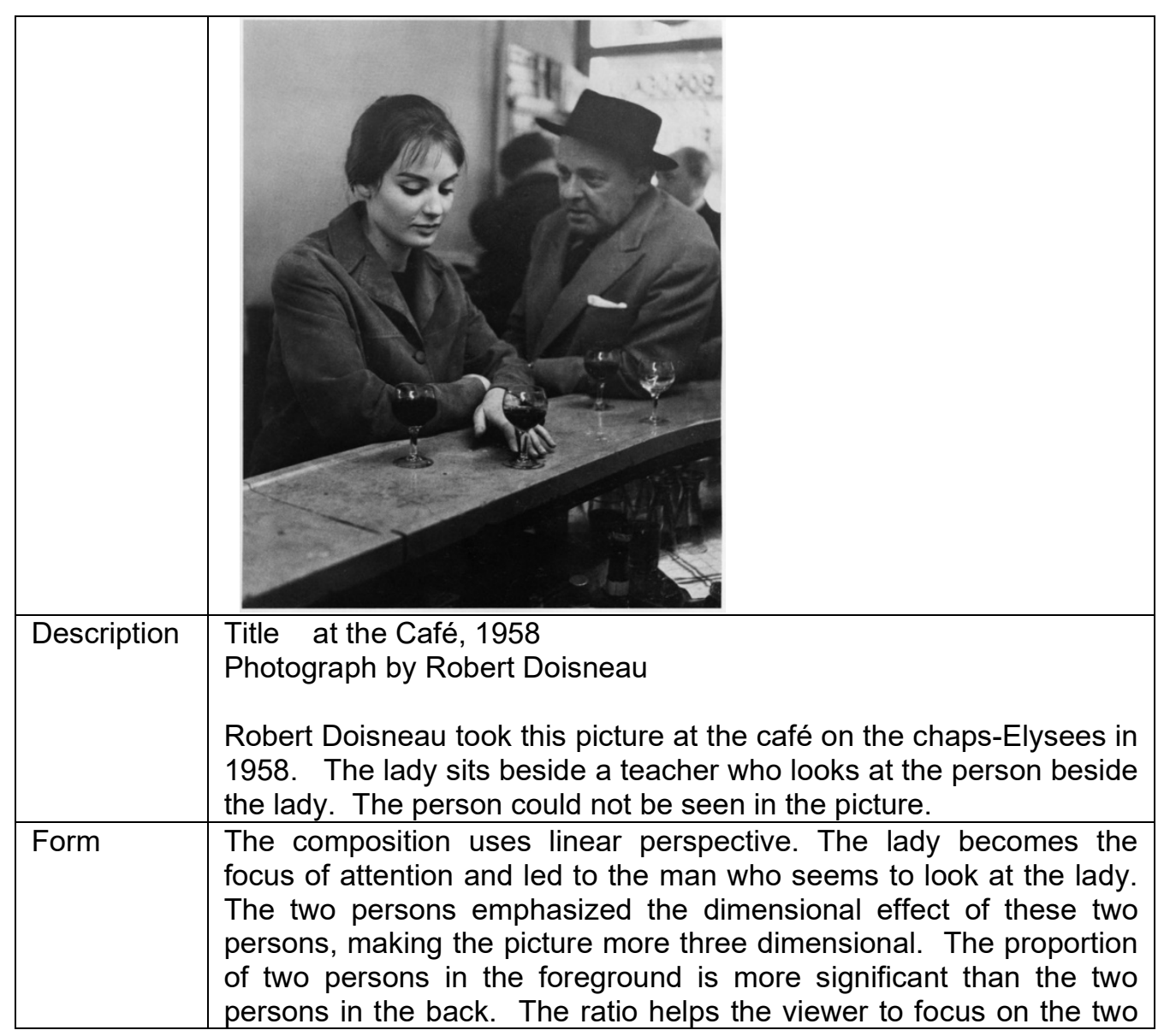




\begin{tabular}{|l|l|}
\hline & persons in the foreground. \\
\hline $\begin{array}{l}\text { Photo } \\
\text { technique }\end{array}$ & $\begin{array}{l}\text { Robert Doisneau took this photo with a black and white film. Robert } \\
\text { used available light, and the light comes possibly from the lamp and } \\
\text { the light from the door in the back. There were no shadows in the } \\
\text { right and left cheek of the lady. The light came from the front of the } \\
\text { lady, and it can be shown in the shade in her coat. }\end{array}$ \\
\hline Medium & $\begin{array}{l}\text { The medium of the photo was a black and white photo. Black and } \\
\text { white are promising in showing the people. }\end{array}$ \\
\hline Denotation & $\begin{array}{l}\text { The man, a teacher, saw a person besides the lady. He probably } \\
\text { talked with his friend at the café on the chaps-Elysees in 1958 }\end{array}$ \\
\hline Style & $\begin{array}{l}\text { This picture showed people were relaxed after they went back from } \\
\text { the office. This picture showed no political or social issues. It just } \\
\text { explained the situation inside the café on the chaps-Elysees. }\end{array}$ \\
$\begin{array}{l}\text { Robert Doisneau was a French photographer. His style was } \\
\text { documentary photographs. He was a photojournalist. Suppose we } \\
\text { compared with his contemporaries, Henry Cartier Bresson. His work } \\
\text { was quite different. Robert Doisneau was known for his model, and } \\
\text { Henry Cartier Bresson was famous for his decisive moments. His } \\
\text { subject matters were probably similar to Henry Cartier Bresson; both } \\
\text { photographers took persons in everyday life situations. Both } \\
\text { photographers like to take in the street. }\end{array}$ \\
\hline $\begin{array}{l}\text { At the Café, 1958, Robert Doisneau's photograph was first published } \\
\text { in Le Point as part of a photo essay on Paris cafés. The photo later } \\
\text { was sold without Doisneaus's consent to a temperance league and } \\
\text { published in a leaflet about alcohol abuse. Again, it was used by a } \\
\text { French gossip tabloid and printed with the caption' Prostitution on the } \\
\text { Champs-Elysees". The caption changed again when this photo was } \\
\text { exhibited and became a permanent collection of The Museum of } \\
\text { Modern Art (Barrett, 2010). }\end{array}$ \\
\hline
\end{tabular}

\subsection{Categories photo}

According to Lester, in the 1930s, general educators started promoting photography in classrooms as a more effective means of teaching art. Lowenfield (1987) offered an extensive outlined curriculum for producing and appraising photographs. The medium of photographs has tremendous varieties, and the photographs are not necessarily made to be published in art books or displayed in a museum. Still, they can be used for advertising and journalistic purposes. Photo theory is constructed to engage the observer in an interpretive argument about photographs without combining all photographs into "art" photographs (Barrett, 1986).

The new category of systems can extend to all types, from family snapshots to sophisticated art, journalistic, scientific evidence, and propaganda (Barrett, 1986; 2006). Photo categories are based not on subject matter or form but rather on how photographs are made to function and how they are used to perform. This system is designed to help viewers think about photographs and especially how to interpret them. Through this system, Barret identifies six categories as follows: descriptive, explanatory, interpretive, ethically evaluative, aesthetically evaluative, and theoretical. 


\subsection{Descriptive photographs}

Descriptive photographs explain their features, people, and objects through visual information with greater or lesser detail and clarity. Photographers who take illustrative photos do this with no other intention than to describe something and accurately record subject matter. These include the photographers who take identification photographs and reproduction artworks. Terry Barrett placed Hiroshi Sugimoto, Lynne Cohen and Mary Alpern in this category, although these photographers' works can be considered art.

\subsection{Explanatory Photographs}

Explanatory Photographs are all photographs that possess descriptive information and provide answers to scientific questions. Most explanatory photographs are dependent on their subject matter and agreed with subject matter related to a specific time and place, and that can be dated by visual evidence within the photographs. Most press photographs can be placed in the explanatory category; however, some can go beyond explaining and evaluate, criticize, or applaud aspects of society and thus be suitable in the ethically evaluative category. Henry Cartier Bresson usually took persons in the street and can be considered as general news photographs. However, some of his photo capturing many important historical events, Soekarno during Independence Day, Gandhi's funeral, the USSR after Stalin's death, and the Cultural Revolution in China.

\subsection{Interpretive photographs}

Interpretive photographs seek to explain how things are, but they do not strive for scientific testing procedures and accuracy as explanatory photographs do. They have rather personal and subjective interpretations, more along the lines of poetry than a scientific report. Interpretive photographs are self-expressive and reveal a lot about the worldviews of the photographers who make them. They are not necessarily logical and sometimes apparently work against logic. Most of Duane Michal's sequences, the three books of Ralph Gibson, and the work of Japanese surrealist photographer such as Michiko Kon would be placed in this category.

\subsection{Ethically Evaluative Photographs}

Ethically Evaluative Photographs offer personal interpretation and make ethical judgements. The photographs describe some efforts of scientific explanations, but they praise or criticize aspects of society. These photographs sometimes involve political topics and usually passionately show how things ought or ought not to be. Thus, they are politically engaged and most often relate to social issues. One of the most famous examples is the Minamata series published in the last book by W. Eugene Smith and his wife, Aileen. The photographs present an account of the struggle between the Japanese village fishermen and farmers of Minamata and the Chisso Corporation over the company's wilful polluting of the sea that resulted in methyl mercury poisoning people lived off 
the contaminated fish they caught in the bay.

\subsection{Aesthetically Evaluative Photographs}

Aesthetically Evaluative Photographs are all photographs that explain aesthetic issues more related to beauty. Photographers in this category show and emphasize the variety of visual forms and how they can be achieved photographically. Furthermore, they show what their photographers consider worthy of aesthetic observation and contemplation and usually involve beautiful things photographed in the most beautiful ways. The most common subject matters are the nude, the landscape, and still life. The nudes are usually faceless and nameless. Sometimes, they are only torsos, male and female nudity, or even just studies of the human form. The subject matter is adequately illuminated, posed, and composed for maximum aesthetic effect. Some examples include black male nudes by Robert Marpletehorp, young nudes by Jock Sturges, black and white nudes by Japanese photographer Eikoh Hosoe, and landscapes by Ansel Adams.

\subsection{Theoretical Photographs}

Theoretical Photographs make up the last category of Barrett's model and include photographs about photography. Photographers in this category remark on art and art-making, social aspects and politics of art, how they are presented, and other theoretical issues related to photography and methods. Feminist photographers belong to this category as they use photographs as a visual type of art criticism that uses pictures rather than words. These photographs can be about other photographs, about the film, and art about art. Cindy Sherman, Barbara Kruger, and Lorna Simpson are all included in this category because their subjects relate to feminist issues and art about art, as would Joel Peter Witkin, whose photographs show old icons in historical paintings and sculptures. These categories are not easily taught to beginners, especially Malaysian Students who have not been accustomed to appreciating arts during their study (Zahar, 2014).

\subsection{Methodology}

As stated before, there were 125 participants, 39 male and 86 female, who took part in this research, making up a total of 94 Malays, 12 Chinese, 16 Indians, and 3 Ibans. All of these were students who took the photography course in semester four at Universiti Malaysia Kelantan, and the results were gathered from them using a questionnaire and a semi-structured interview. Their task was to judge photographs from five categories: advertising, journalistic, landscape, modernist photograph and postmodernist photograph. They then answered the three questions we were using as research instruments for each photo: What do you see? What does it mean? How do you know? We used the Barrett criticism models to teach, make a rubric, and evaluate the photographs and research instruments to make photo taxonomy to be used as a guide for lesson plans. "What do you see?" is a question to ask the students for their descriptions of the photographic images. "What does it mean?" is a question to ask the denotation and connotation and resemblance among diverse art objects from an artist, 
movement, period, or geographic location and is recognized by characteristic handling of subject matter and formal elements." How do you know?" is a question to ask the external context.

Photographic lesson plans were delivered during 14 different meeting times, which consisted of 9 sessions discussing the camera, lens, ASA, depth of field, and other technical photographic aspects, and five sessions explaining Barrett's Criticism Model. Participants were given a pre-test and post-test using five pictures and three questions (Chia, 2005, Zahar, 2010): What do you see? What does it mean? How do you know? (Barrett, 2006). Furthermore, we showed the same five images again at the end of the course using a Likert scale. We interviewed ten students with five pictures consisting of a 90s fashion photo from Vogue Magazine, a journalistic photo by Sebastio Salgado, Tettons and Snake River by Ansel Adam, Ireland 1979 Harry Callahan, and You're Fine, 1988 by Lorna Simpson.

Most students could answer the questions about the subject matter, photo techniques, element and principal of design, and the connotations of the advertising, journalistic, and landscape photographs and cityscape, but they found it challenging to interpret Lorna Simpson's photo. Most of the participants said that the picture was related to a medical check-up because they read the text inside the photo panels. Almost none of the students knew the definition of feminist, and some could not identify the person's face in the photo either. Overall, the taxonomy photographs were contingent upon the evaluation the student gave during the pre and post-test, interviews, and questions carried out during the material delivery and their answers on the Likert scale.

\section{$5.0 \quad$ Results}

Richard Avedon's commercial pictures, Sebastio Salgado's two farmer cuttings, Lorna Simpson's fine art shot, You're Fine, Ansel Adams' scenery, and Harry Callahan's Ireland are the five photos we chose. The subject matter, medium, form, and context of photographs all influence their meaning (Barrett, 2006). During a lecture or webinar, the majority of participants can generally answer questions regarding the subject matter without difficulty, especially when it comes to human activities. If the subject matter represents something (symbolize), it will become more challenging.

According to Barrett, the medium is the topic of art, such as painting or photography, and it is easy to identify until some of the images are placed on billboards or other public areas, such as Barbara Kruger's art, where graphic design and photographs are difficult to separate. Form is used to define not just the principles of art, but also to connect to photographic style. Humans are frequently utilized as points of interest in photojournalism, and the person is cast as an actor in the photo story. In most cases, students had little trouble interpreting the photo story. The students, on the other hand, struggled to understand the meaning of abstract images. They are typically encouraged to study composition and the links between the many elements of art in more depth. Non-human subjects and non-objective works of art are common in abstract photography (Non-objective art is defined as having no recognizable subject matter).

The title, date, and maker of a photograph, as well as presentational and causal contexts, are all part of the context. Certain fine art and postmodernism pictures are 
more difficult to comprehend in context as compared to modernist photography. During the 1990s, Oliviero Toscani created advertisements for Bennetton. Many sensitive subjects in journalistic pictures were transformed into Bennetton advertisements, such as the infant with Aids, Chinese and Tibetian monks, and so on. Students found it difficult to comprehend Oliviero Toscani's commercials if they were unfamiliar with the concerns and stories behind them (zahar, 2010). We attempt to organize the images into categories so that selecting photos for teaching is easy as indicated in Table 3.

We examine the result of pre and post-test, students answer no 1. What do you see? The answer found it challenging to explain the photo technique of photo no 3 . You're Fine by Lorna Simpson, and most of the student can understand the photo technique no 1. photo ads in Vogue magazine. The student also can explain the lighting and principle of design in photo no 1. during an interview. Students also have no problem answering a question no 2 . What does it mean? The student is easily understood the context and content no 1 . Vouge ads. They found it challenging to understand the meaning of photo no 3. Most of the student answers that the woman is going to a medical check-up. They read the typography in the photo.

During the interview, students have little knowledge about the history of Afro-American, American culture and feminism. Culture plays an essential role in the learning process as Vygotsky pointed that "what we learn we learn from others" (Phillips dan Soltis, 2004). Most of the students' answers did not discuss feminist and race discrimination in photo no 3. However, one student can mention that the woman is depressed because she seems that she is under control by somebody and cannot speak. She is just a subordinate or become a victim. Teaching students to understand and interpret photos and consider the student's culture is crucial when planning the lesson. The lecturer can use photo to teach other social culture or other ideology which is not part of the student's culture.

Students have no problem interpreting Sebastio Salgado's photograph of one farmer who harvests the farm. They said that the people work very hard, property and mention them as a farmer. They found it a bit easier to interpret Ansel Adam's photograph. They said the lighting is excellent and outstanding, and the clouds are beautiful, grandeur, sad, romantic, spacious. Harry Callahan shows Ireland houses without any people inside of photo no 5 . The student interprets that the place is empty, in harmony with one perspective. Students answer no 3. How do you know? The student explains the know the photo from photo technique for no 1., the activity of the farmer for no 2 ., the text in the photo for no 3., the student found from the article for no 4., and composition and colour for no 5 as indicated in Table 4.

After post-test, we gave a Likert test with five photos. 26 students did not attend. The results show in sequence from easy to complex, no $1,2,4,5$, and 3 . This similar sequence was shown during the interview. 
Table 3: The best answer from the participants

\begin{tabular}{|c|c|c|c|c|}
\hline & Photograph & $1^{\text {st }}$ question & $2^{\text {nd }} q u e s t i o n$ & $3^{\text {rd }}$ question \\
\hline 1 & & $\begin{array}{l}\text { The photo shows } \\
\text { the high key } \\
\text { technique. } \\
\text { Balance is made } \\
\text { by the two } \\
\text { models. The } \\
\text { direction of light } \\
\text { from both sides, } \\
\text { this type of photo } \\
\text { is usually used } \\
\text { for advertising } \\
\text { and product } \\
\text { promotion. }\end{array}$ & $\begin{array}{l}\text { The two models } \\
\text { show happiness } \\
\text { and use Versace } \\
\text { product. The } \\
\text { meaning of this } \\
\text { photo is to attract } \\
\text { viewers to use } \\
\text { the products } \\
\text { which were } \\
\text { offered. This ad } \\
\text { tries to promote } \\
\text { the product. }\end{array}$ & $\begin{array}{l}\text { The models show } \\
\text { their expressions } \\
\text { and gestures. } \\
\text { The } \\
\text { photographer } \\
\text { uses a bright light } \\
\text { which always } \\
\text { used advertising in } \\
\text { advertion }\end{array}$ \\
\hline 2 & & $\begin{array}{l}\text { I see the depth of } \\
\text { field in the front } \\
\text { and the back of } \\
\text { the photograph. } \\
\text { The photograph } \\
\text { shows the } \\
\text { person who } \\
\text { holds the knife is } \\
\text { the main subject. } \\
\text { The direction of } \\
\text { light came from } \\
\text { the left side. This } \\
\text { picture uses } \\
\text { emphasize the } \\
\text { concept. This } \\
\text { type of photo is } \\
\text { photojournalism. }\end{array}$ & $\begin{array}{l}\text { Two persons } \\
\text { work very hard to } \\
\text { clean the weeds } \\
\text { with different } \\
\text { expressions. }\end{array}$ & $\begin{array}{l}\text { I know this photo } \\
\text { because the } \\
\text { difficulty of } \\
\text { people working. }\end{array}$ \\
\hline 3 & & $\begin{array}{l}\text { I see a woman } \\
\text { divided into four } \\
\text { sections and the } \\
\text { writing was } \\
\text { confined into } \\
\text { rectangular. }\end{array}$ & $\begin{array}{l}\text { The woman is } \\
\text { depressed } \\
\text { because she } \\
\text { seems that she is } \\
\text { under control by } \\
\text { somebody, and } \\
\text { she cannot } \\
\text { speak. She is } \\
\text { just a subordinate } \\
\text { or become victim. }\end{array}$ & $\begin{array}{l}\text { The woman lay } \\
\text { down faceless. } \\
\text { The picture is } \\
\text { arranged in a } \\
\text { way that the } \\
\text { woman cannot } \\
\text { escape from that } \\
\text { situation. }\end{array}$ \\
\hline 4 & & $\begin{array}{l}\text { I see landscape } \\
\text { picture with } \\
\text { interesting } \\
\text { composition. } \\
\text { The depth of field } \\
\text { is clear and show } \\
\text { front side, middle } \\
\text { and background. } \\
\text { The gradation of } \\
\text { black and white } \\
\text { is clear from } \\
\text { white into black. }\end{array}$ & $\begin{array}{l}\text { The photo show } \\
\text { harmony and } \\
\text { tranquillity of } \\
\text { nature. The photo } \\
\text { was taken by } \\
\text { Ansel Adams }\end{array}$ & I read from article \\
\hline
\end{tabular}




\begin{tabular}{|l|l|l|l|}
\hline 5 & $\begin{array}{l}\text { Perspective with } \\
\text { one vanishing } \\
\text { point }\end{array}$ & $\begin{array}{l}\text { Calm, it seems } \\
\text { that the place is } \\
\text { empty. }\end{array}$ & $\begin{array}{l}\text { can feel the } \\
\text { depth of field } \\
\text { because this } \\
\text { photo shows the } \\
\text { distance. }\end{array}$ \\
\hline
\end{tabular}

Table 4: The result of Likert scale of the photograph interpretation after pretest and posttest.

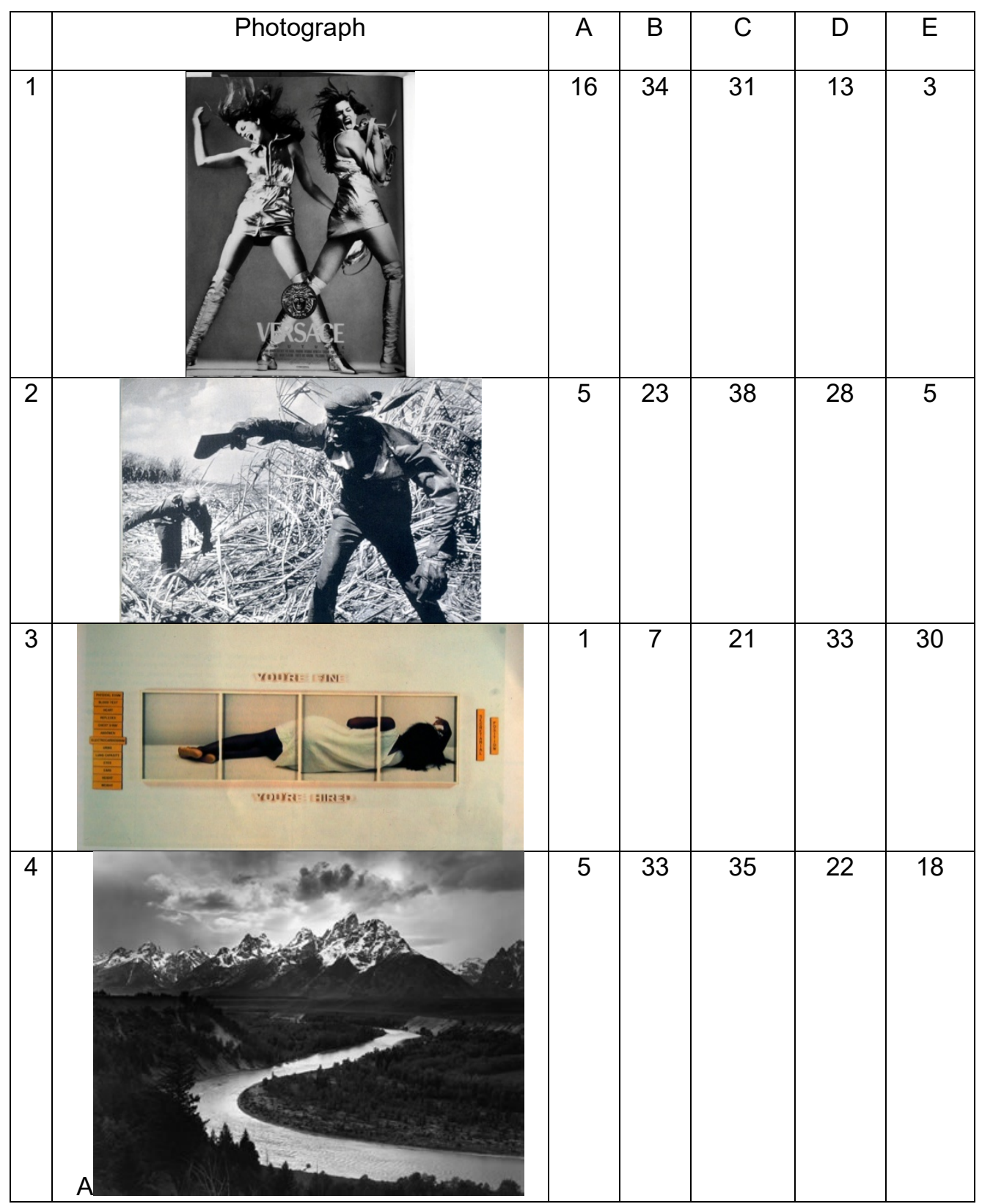




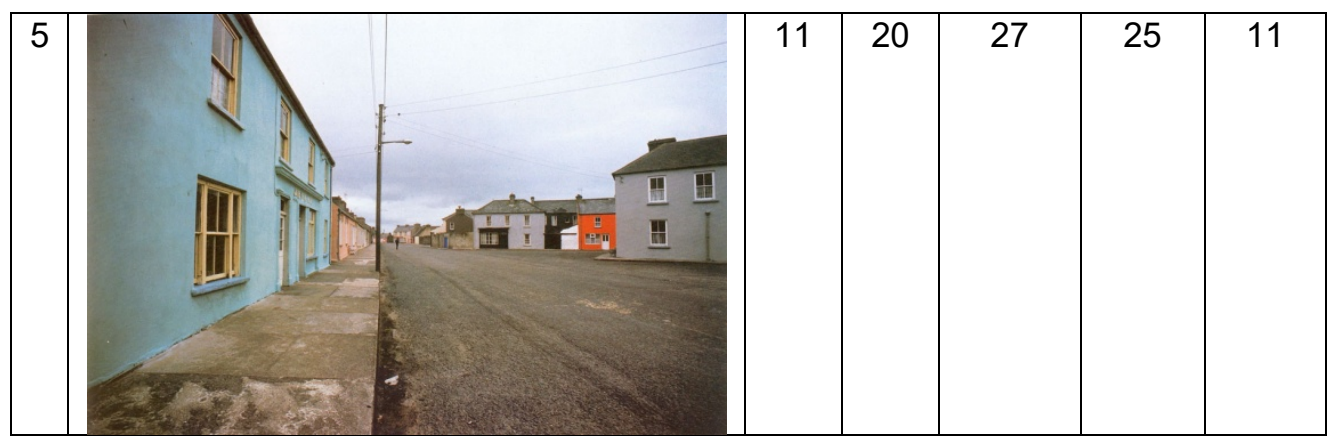
A : Very Easy
B : Easy
C : Moderate
D : Difficult
E : Very Difficult

\subsection{Discussion}

This research produced categories for teaching photography starting from a low to high taxonomy as follows.

\subsection{Descriptive photographs}

These photographs do not arouse feeling. The photographer takes pictures that are not meant to be any more than descriptions. These can include identification photographs, medical $X$ rays, photomicrographs, and reproductions of artworks. 160 photographs of Karmawibhangga's from Borobudur reliefs were documented by Kasian Chepas, an Indonesian pioneer in modern photography during Dutch colonials, who took the Karmawibhagga at the end of 19th century (Sunaryo, 2010). Although Kasian Chepas made a lot of portraits of the Javanese Royal Family that can all be considered as art, his 160 photographs of Borobudur reliefs were not actually intended to be so. Likewise, Terry Barrett (2006) placed Hiroshi Sugimoto's photographs of movie palaces and drive-in theatres, as well as Lynne Cohen's photographs of complex institutional interiors in the descriptive category. Both artists do, in fact, make descriptive photographs as art. However, this research aims to categorize descriptive photographs not intended to be art, but mere description photographs, as accurately as possible. These photographs, therefore, will be categorized as the lowest in this taxonomy as they are easy to identify and describe.

\subsection{Advertising photographs}

The advertising image is frank, the meaning of the image is intentional; the signifiers of the advertising message are formed a priori by characteristics of 
the products and have to register as clearly as possible. Advertising photographs will make a person feel intimate, fearful, and they sell sexuality (Barthes, 1977). They are placed in the ethically evaluative category and are understood to be "propaganda" (Barrett, 2006). When we asked questions during the course, the pre and post-test, and the interview, the messages of these photographs were easy to interpret. Despite the fact that Benneton used a World Press awarded photo (journalistic photo) as part of their United Colours promotional campaign, students still found that the 1980s Benneton ads by Olivera Toscani were more difficult to interpret than ordinary advertising photographs. The Benneton ads by Olivera Toscani can be placed in the category of Postmodernist photographs because the concept of producing the art works resemble a postmodernist concept that does not emphasize originality. In relation to Barrett's categories, both journalistic photographs and advertising photographs are included in the ethically evaluative category of which journalistic photographs are the more difficult to interpret for UMK students.

\subsection{Journalistic photographs}

Photo historians have commonly divided the work of documentary photographers into two categories: straight documentary and social documentary. The first are the photographers who capture specific ways of life before they have vanished from an ever-changing world. On the other hand, those who make social documentaries tend to specialize in a specific social subgroup- sulphur miners of ljen Volcano in Java, workers in draught areas such as Kidul Mountain in Java, or even members of an inner-city gang. The photographers draw attention to the individuals and the specific things that sometimes connote negative conditions and experiences, things that need to be reformed (Sandler, 2002). Photojournalism can further be divided into three categories, such as spot news, general news and essay photographs.

Spot news or breaking news photography is an unscheduled and unfolding news event for which there is no opportunity for planning (Fischer dan Fischer, 2003). Usually, these photographs will make a person feel sad, depressed, scared, or evoke other negative feelings. One of the most famous spot news photographs is Nick Ut's photo which features a Vietnamese girl suffering through a napalm bomb attack during the Vietnam War. General news covers a planned or unplanned news event, or a subject of general interest and importance. The photographers need to produce a picture that will have an impact as well as the ability to portray the character of a particular personality or event (Wright, 1999).

A photo essay is a sequence of photographs that conveys a story. Photojournalists are required to own special skills in order to compile their photographic stories, or photo essays. They have the ability to capture a sequence of images that create the story all the way from the beginning to the end. This type of assignment can be planned a week in advance (Wright, 1999) and in the case of photographer W. Eugene Smith, was undertaken for more than four years in Japan. His famous and most striking photo of the 
essay was Tomoko Uemura in Her Bath, (1972) that shows Ryoko Uemura, holding her severely deformed daughter, Tomoko, in a Japanese bath chamber. We found that most of the participants had no problems responding to this kind of photojournalism and could understand the message of the photographs. Students could even name the activity of the farmers in Salgado's photographs and some of them also knew the photographs' connotations. This part of our research did not use Spot News and General News photographs, but these kinds of feature and essay photographs which give an additional historical dimension and places the image in a broader narrative context.

\subsection{Modernist Photography (fine art)}

Even after the first photograph in the world, the view from his window in Le Gras, was taken in 1827 by Nicephore Niépce, photography was still not considered as art. It was not until the 1950s that two English photographers, Oscar Rejlander and Henry Peach Robinson, pioneered photography as an art. (Robinson, 1869, Sandler, 2002). While acknowledging that pictorialism is a part of modernist photography, we still did not use any photographs of Alfred Stieglitz, Edward Steichen, James Craig Annan and any pictorialized photographs (1896-1916). Pictorialism tries to imitate painting styles, and Edward Weston criticized the "pseudo-paintings" of photographers who visibly hand-brushed their emulsions. Modernists emphasize symbolist rather than narrative photographs, and favor realism over instrumentalism. Modernists believe the straight photograph to be an example of what photography does best. Prints are valuable, signed, numbered, and processed in an archival manner (Barrett, 2006). This lead to the key principles of modern photographic practices; (1)the photographers should find their subjects, (2) photographers are not allowed to make alterations of any kind to the segment of reality chosen, (3) photographers try to render things as "objectively" as they find them, (4) no manipulations of the exposed negative are permitted in the darkroom, (5) photographic prints should show the higher technical perfection and contain a range of grey tones,(6) the photographers creative achievement is based on their choice of motifs which also depend on the camera view, focal length and exposure time (Köhler, 1989). Group f.64 is probably the most famous movement in the history of photography, and this movement was equally defined by women.

The members are Ansel Adams, Imogen Cunningham, Dorothea Lange, Willard Van Dyke, and Edward Weston. This group f.64 contributed significantly to the recognition of photography as a fine art (Alinder, 2014). Most of the students at UMK could identify the subject matter and describe the form of Tettons and Snake River by Ansel Adam, yet it was the connotations of Ireland, by Harry Callahan which they found more difficult to interpret. Ansel Adams photographs usually can be placed as aesthetically evaluative photographs within Terry Barrett's categories. However, Ireland and most of Harry Callahan's color photographs in the book titled Harry Callahan's New Color Photographs 1978 1987, were made on the streets of several countries. Callahan did not try to make his photographs relate to beauty, and they cannot be placed in the same category as aesthetically evaluative photographs. Some of his works are 
abstract; therefore, they become difficult for students to interpret. Formalism is another aesthetic theory which supports abstraction, nonrepresentational imagery and minimalist art and is related and associated with Modernism. Context was ignored and criticism did not rely on history or biography or the psychology of the artist (Barrett, 2006). Many of Edward Weston's and Ansel Adams' photographs are realist and students can identify the subject matter relatively easily without really needing to know about the biography and psychology of the artist.

\subsection{Postmodernist photograph}

This research used Lorna Simpson's photo titled You're Fine, 1988. (Aperture, 1993). The American artist Lorna Simpson has confronted feminist issues about the treatment of women and also different races in art and society. The image shows a combination of text and imagery that raises questions about gender and racial identity and features a woman lying on an examination table wearing a nondescript white slip. However, students found this picture was the most difficult to interpret. Most of them did not know the definition of the word "feminism" and they could not even identify the race of the woman in the picture. Even though, students can be divided into three main ethnic groups, Malay, Chinese and Indian, most of them were not exposed to ideological differences during their high school years. The issues concerning postmodernist artists have not been well exposed to them in their courses, and even in the art exhibitions in Malaysia.

\subsection{Conclusion}

Regarding Terry Barrett's criticism model, UMK students were easily able to describe the subject matter of fine art in modernist, commercial, and journalistic photographs. They also had no difficulties in describing the technical side of the photographs as well as their forms. To properly analyze a photographer's work, however, is to compare and contrast it to another work by the same photographer, as well as to other photographers' works (Barrett, 2006). This activity is what became elusive for students, especially when they had to describe the style of photographers. This difficulty has come about due to the lack of photography history taught in our visual communication design course. Students can understand the context of a photo when it relates to the history and culture of Malaysia, but they cannot describe a photo which relates to world history or general knowledge outside of the course curriculum. Photography is only one subject in the visual communication design course, and we have to find a balance between the technical side of photography and appreciation. The taxonomy of the photographs will be overlapped, but not all modernist photographs will be easy to interpret. Ralph Gibson's photographs will be quite difficult because his photographs are cropped tightly and only show a small amount of information about the subject matter. Ads photographs will usually be easy to interpret, however some of the controversial photographs by Olivera Toscani will not. Besides taxonomy photographs, this research showed that student's appreciation skills within Barrett's Criticism Model (Chia, 2005, Zahar, 2010) started from the easiest to the most difficult: subject matter and medium, form, context, and then style. Style is the most difficult characteristic to interpret, especially for postmodernist photographs. This combined with their context 
will make them overall the most challenging photographs to analyze, and even more so if the pictures have social issues and contexts which are outside of students' knowledge range. Feminist issues are not strong in Malaysia, and this is particularly true in Kelantan, as students have never been exposed to these social issues in art courses. Furthermore, most students are beginners, and their interest lies more within the technical aspects of photography rather than photo criticism.

\section{References}

Alinder, M. (2014). Group f.64: Edward Weston, Ansel Adams, Imogen Cunningham, and the Community of Artists Who Revolutionized American Photograph. USA: Bloomsbury.

Aperture. (1993). on location with Annie Leibovitz, Lorna Simson, Susan Meiselas, Cindy Sherman, Adam Fuss, Joel Peter Witkin, Jon goodman (Vol. 133). New York: Aperture Foundation.

Barrett, T. (1986). A Theoretical Construct for Interpreting Photographs. Studies in Art $\begin{array}{llll}\text { Education, } & 27(2), & \text { 52-60. } & \text { Retrieved }\end{array}$ http://www.jstor.org/page/info/about/policies/tems.jsp

Barrett, T. (1997). Modernism and Postmodernism: An Overview with Art Examples. In J. Hutchens, dan M. Suggs (Eds.), Art Education: Content and Practice in a Postmodern Era Reston (pp. 28-29). National Art Education Association. Retrieved from Retrieved from: http://www.terrybarrettosu.com/pdfs/B_PoMo_97.pdfBright

Barrett, T. (1997). Photographs and Contexts. In T. Barrett, D. Goldblatt, dan L. Brown (Eds.), Aesthetics: A Reader in Philosophy of the Arts. Prentice-Hall.

Barrett, T. (2000). Criticizing Art: Understanding the Contemporary. New York: McGraw Hill.

Barrett, T. (2006). Criticizing Photographs, An Introduction to Understanding Images (4 ed.). Boston: Mc Graw Hill.

Barrett, T. (2010). Photographs and Contexts. In D. Goldblatt, dan L. B. Brown, Aesthetics: A Reader in Philosophy of the Arts. Pearson.

Barrett, T. (2010). Principles for Interpreting Photographs. In J. Swinnen, L. Deneulin, J. Swinnen, dan L. Deneulin (Eds.), The Weight of Photography: Photography History Theory and Criticism (pp. 147-172). Brussels: ASP.

Barthes, R. (1977). Image-Music-Text. (S. Heath, Trans.) New York: Hill and Wang.

Becker, H. S. (1998). Visual Sociology, Documentary Photography, and Photojournalism: It's (Almost) All a Matter of Context. In J. Prosser, Image-bsed Research: A Sourcebook (1 ed.). New York: Routledge Falmer.

Broudy, H. S. (1986). Once More with Feeling. The Journal of Aesthetic Education, 20(4), 19-

21. doi:10.2307/3332591 
Chia, C. C. (2005). A Descriptive Case Study of Impact of Professor's Teaching Strategies on Taiwanese College Students'photographic image interpretation. The Pennsylvania State University.

Clements, R. D. (1979). The Inductive Method of Teaching Visual Art Criticism. The Journal of Aesthetic Education, 13(3), 67-78.

Feldman, E. B. (1994). Practical Art Criticism. New Jersey: Prentice Hall.

Fischer, H.-D., dan Fischer, E. (2003). Complete Historical Handbook of the Pulitzer Price System 1917-2000. Berlin: De Gruyter.

Frawisandi, H. (2015). Fotomontase Sebagai Media Kritik Fotografi Program Studi Fotografi Dan Film.unpulished bachelor report, Universitas Pasundan.

Gaya, M. D. A. N. (2019). Kritik fotografi: mendeskripsikan sebuah foto dari sisi subjek, bentuk, media dan gaya. 16(1), 85-96.

Hamblen, K. A. (1984). An art Criticism Questioning Strategy within the Framework of Bloom's Taxonomy. Studies in Art Education, 26(1), 41-50. doi:10.2307/1320799

Johansen, P. (1979). An Art Appreciation Teaching Model for Visual Aesthetic Education. Studies in Art Education, 20(3), 4-14.

Köhler, M., Vowinckel, A., dan Felix, Z. (1989,). Constructed Realities: The Art of Stage. Switzerland: Edition Stemle.

Lankford, E. L. (1984). A Phenomenological Methodology for Art Criticism. Studies in Art Education, 25(3), 151-158. doi:10.2307/1320696

Lowenfeld, V., dan Lambert, W. (1987). Creative and Mental Growth (8 ed.). New York: Macmillan.

Mitler, G. (1980). Learning to look/looking to learn: A Proposed Approach to Art Appreciation at The Secondary School Level. Art Education, 33(3), 17-21.

Prater, M. (2002). Art Criticism: Modifying the Formalist Approach. Art Education, 55(5), 12-17.

Rafika Dhona, H., dan Astari, W. (2020). Kritik Terhadap Tren Wisata Foto di Indonesia: Kasus Tebing Breksi Yogyakarta. Tuturlogi, 1(2), 93-105. https://doi.org/10.21776/ub.tuturlogi.2020.001.02.2

Robinson, H. (2014). Combination Printing. In Pictorial Effect in Photography. In A. Herschberger, Photographic Theory an Historical Anthology (1 ed., pp. 88-90). New Jersey: Wiley Blackwell.

Sandler, M. W. (2002). Photography An Illustrated History. New York: Oxford University Press Inc.

Sunaryo, A. (2010). Aneka Ornamen Motif Flora pada Relief Karmawibangga Candi Borobudur. 
Imajinasi, VI(no 2), 113-125.

Ward, J. (1970). The Criticism of Photography as Art: the photographs of Jerry Uelsmann. Gainsville: University of Florida Press.

Wulandari, W. (2017). Kajian foto Ruang Bermain sebagai Kritik terhadap Ruang Publik. Jurnal Desain, 4(02), 120. https://doi.org/10.30998/jurnaldesain.v4i02.980

Zahar, I. (2010). Pengembangan Model Pembelajaran Berbasis Masalah untuk Interpretasi Foto. Jakarta: Universitas Negri Jakarta.

Zahar, I. (2015). Photo Exemplar Classification: The Integration of Photographic Technique. In O. H. Hassan, S. Z. Abidin, R. Legino, R. Anwar, dan M. F. Kamaruzaman (Eds.), International Colloqium of Art and Design Education Research (i-CADER 2014) (1 ed., pp. 161-172). Singapore: Springer-Verlag. doi:10.1007/978-981-287-332-3_18

Zahar, I (2021). Kritik Foto dan Perkembangannya. unpublished manuscript, LPPM's report Universitas Esa Unggul. 